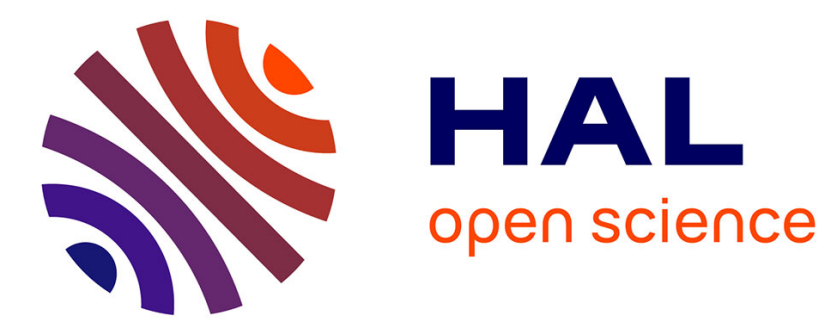

\title{
Spirituality and Cancer: a Qualitative Study
}

Laura Estienne, Lionel Dany, Eric Dudoit, Florence Duffaud, Sebastien Salas

\section{To cite this version:}

Laura Estienne, Lionel Dany, Eric Dudoit, Florence Duffaud, Sebastien Salas. Spirituality and Cancer: a Qualitative Study. Psycho-Oncologie, 2019, 13 (3-4), pp.173-182. 10.3166/pson-2019-0105 . hal02527315

\section{HAL Id: hal-02527315 https://hal-amu.archives-ouvertes.fr/hal-02527315}

Submitted on 1 Apr 2020

HAL is a multi-disciplinary open access archive for the deposit and dissemination of scientific research documents, whether they are published or not. The documents may come from teaching and research institutions in France or abroad, or from public or private research centers.
L'archive ouverte pluridisciplinaire $\mathbf{H A L}$, est destinée au dépôt et à la diffusion de documents scientifiques de niveau recherche, publiés ou non, émanant des établissements d'enseignement et de recherche français ou étrangers, des laboratoires publics ou privés. 
Laura Estienne $(\square)$

Psychologue

Aix Marseille Univ, LPS, Aix-en-Provence, France

APHM, Timone, Service d'Oncologie Médicale, Marseille, France

Estienne.Laura@outlook.fr

\section{Lionel Dany}

Professeur de Psychologie Sociale

Aix Marseille Univ, LPS, Aix-en-Provence, France

APHM, Timone, Service d'Oncologie Médicale, Marseille, France

Aix Marseille Univ, CNRS, EFS, ADES, Marseille, France

e-mail: Lionel.Dany@univ-amu.fr

Eric Dudoit

Docteur en Psychologie

APHM, Timone, Service d'Oncologie Médicale, Marseille, France

e-mail: Eric.Dudoit@mail.ap-hm.fr

Florence Duffaud

Professeure de Médecine

APHM, Timone, Service d'Oncologie Médicale, Marseille, France

e-mail: Florence.Duffaud@mail.ap-hm.fr

\section{Sébastien Salas}

Professeur de Médecine

APHM, Timone, Service d'Oncologie Médicale, Marseille, France e-mail: Sebastien.Salas@mail.ap-hm.fr 
Spirituality and cancer: a qualitative study

Spiritualité et cancer : une étude qualitative 


\section{Résumé :}

Contexte : Les malades du cancer sont souvent confrontés à une prise de conscience de leur propre finitude et au fait de composer avec une vie désormais rythmée par le cancer. $\mathrm{Ce}$ bouleversement existentiel peut s'accompagner d'un «travail» spirituel qui contribue à l'ajustement à la maladie et aux conditions de la fin de vie. La spiritualité peut être définie comme un processus par lequel les individus cherchent et donnent du sens à leur vie, se sentent connectés à soi, aux autres, au moment présent et à ce qui est sacré. Très peu d'études en France s'intéressent à la spiritualité dans le contexte du cancer. Ainsi, l'objectif de notre étude était d'identifier et d'étudier le rôle des composantes spirituelles dans le vécu de la maladie cancéreuse.

Méthodologie : Nous avons réalisé 15 entretiens semi directifs auprès de patients du service d'oncologie médicale et de soins palliatifs du CHU de la Timone (Marseille). Une double analyse a été réalisée : (1) une analyse lexicographique et (2) une analyse thématique ciblée sur les entretiens les plus typiques issus de l'analyse lexicographique.

Résultats : L'analyse lexicographique a mis en évidence trois classes lexicales. La classe 1 renvoie à l'expérience vécue du cancer ainsi qu'aux transformations et réaménagements internes $(40,5 \%)$, la classe 2 est relative à la rupture biographique constitutive du vécu expérientiel du cancer $(13,4 \%)$ et la classe 3 correspond à la description du vécu quotidien du cancer $(46,1 \%)$. En complément, l'analyse thématique fait apparaitre différents thèmes témoignant de la spiritualité dans l'expérience vécue du cancer, notamment l'expérimentation et la relation au sacré, la relation à la transcendance et le rôle de la spiritualité dans le vécu expérientiel des patients.

Conclusion : L'analyse des entretiens a permis d'identifier l'expression de composantes spirituelles. Elles s'expriment comme une ressource, un « ressort invisible » afin de permettre l'ajustement à l'expérience extrême de la maladie cancéreuse. Les deux dimensions centrales « laïques » de la spiritualité : la transcendance et la relation au sacré ouvrent des perspectives pour l'intégration de la spiritualité dans la prise en charge des patients atteints de cancer, sans remettre en cause le principe de laïcité des hôpitaux français.

Mots clés : spiritualité, cancer, coping, expérience vécue. 


\section{Summary:}

Aims: Patients suffering from cancer are often confronted with an awareness of their own finiteness and with the fact that their life is now ruled by the cancer. This existential upheaval can be accompanied by spiritual "work" which contributes to the adjustment to the disease and to the conditions of the end of life. Spirituality can be defined as a process through which individuals seek for and give meaning to their life, feel connected to the self, to others, at the present moment and in what is sacred. Few studies in France have studied spirituality in the context of cancer. So, the aim of our study was to identify and to study the role of spiritual components in the experience of cancer.

Procedure: We carried out 15 semi-directed interviews with patients at the medical oncology and palliative care department at the CHU in Timone (Marseille). A double analysis was performed: (1) a lexicographical analysis and (2) a thematic content analysis of the most typical interviews from the lexicographical analysis.

Results: The lexicographical analysis highlighted three lexical classes. Class 1 represented the illness of cancer as a personal transformation (40.5\%), Class 2 concerned the biographical disruption experience $(13,4 \%)$ and Class 3 corresponded to daily life with the illness $(46.1 \%)$. Moreover, the thematic content analysis revealed different themes testifying to spirituality in the lived experience of cancer, in particular the experience of and the relationship with the sacred, the relationship with transcendence and the role of spirituality in the lived experience of patients who are suffering from cancer.

Conclusion: The two analyses of the interviews allowed us to identify the expression of spirituality. Spirituality was expressed as a resource, a " invisible spring", allowing people to adjust to the extreme experience of the disease of cancer. Both "secular" and central dimensions of spirituality: the transcendence and the relationship with the sacred open perspectives for the integration of spirituality into the care of patients suffering from cancer, without threatening the principle of secularism in French hospitals.

Key words: spirituality, cancer, coping, lived-experience 


\section{Introduction}

Suffering from cancer means not only having a disease but also seeking to make sense of a personal experience in a specific sociocultural context. The relationship between the patient and the illness is shaped by the relationships that the patient maintains with others, relationships which are also imbedded in a cultural background which constitutes a reservoir of meanings. This set of relationships shape the patient's experience and allow them to make sense of their experience [1]. Bio-psycho-social consequences of cancer associated with illness representations of this disease contribute to the development of an existential wound [2]. There was a need to view existential questioning as a possibility for development and not as a symptom to be suppressed, "medicalized" or ignored [3]. Existential questioning involves introspection, rethinking values, the meaning of life and reflecting on the future $[4,5]$. This existential quest is often studied as spiritual work contributing to adjustment to a cancerous disease.

In health psychology, spirituality is presented as an essential part of care centred on the person because it could be an important factor in adjustment at every moment in cancer (diagnosis, treatment, remission, recidivism and end of life [6]. In order to study spirituality, it seems essential firstly to define what spirituality is and the necessity of differentiating this concept from religiosity. These concepts are not opposable, but the religious is only an epiphenomenon of the spiritual $[7,8,9]$. Indeed, the spiritual dimension exists beyond religion because we should not be obliged, when we talk about spirituality, to affiliate it with a specific belief or a particular god [10]. Spirituality can be defined as the capacity of individuals to search and make sense of their life and to feel connected at the present moment, to the self, others, nature and the sacred [11].

When talking about spirituality it seems essential to take into consideration the notions of the sacred and transcendent. For example, for many authors, spirituality could be defined and 
distinguished from humanism, values and morality by the presence of the sacred and transcendent [12]. Sacred corresponds to a god, a higher divine power, a transcendent reality [13]. It should be made clear that the sacred concerns religion as well as other secularist aspects of life which become extraordinary for the individual through the "sanctification" process $[13,14]$. Transcendence can be defined as believing in a higher being or superior personal strength, which can be other than "god-based religion", with which the individual has a relationship [15]. Thus, spirituality allows us to find meaning and goals beyond boundaries, through connection and relationships (in an authentic way) with others, the self, the environment or transcendence and the sacred [16].

Research into psycho-oncology indicates that spirituality promotes the empowerment of patients suffering from cancer, in the way patients overcome obstacles [17]. Spirituality makes it possible for individuals to make sense of their experience, and to deal with cancer. This strength is based on the capacity to "refer to a higher power", in other words, to find "a place and a time of peace to create for oneself" [7]. Patients suffering from cancer find reassurance in religion and/or spirituality [18]. Studies highlight the fact that spirituality (or spiritual wellbeing) is a resource which can help cancer patients to adjust $[6,8,9,17]$, make it possible to cope with illness and can have a significant influence on satisfaction with life, depression and quality of life $[6,19]$. Other studies [20] have shown that spirituality maintains or increases well-being despite symptoms of the disease and the incertitude caused by cancer. Moreover, spiritual wellbeing promotes the expression of positive feelings [21]. In contrast, patients with a low level of spiritual well-being express more despair [22]. Therefore, according to these studies, spirituality seems to play a significant role in helping people cope with cancer. Despite these results, there are few studies on this topic in France.

The aim of this study was to examine, in a comprehensive and contextual perspective, whether we could identify components of spirituality in the patient's discourse on their illness in the 
French context. In addition, we wanted to provide some reflections on the issues involved in considering spirituality in the distinctive experience of cancer and on how spirituality could help people cope with cancer.

\section{Method}

\section{Participants}

Participants were patients with cancer, hospitalized in the oncology department of a University Hospital in Marseille (France). A total of 15 patients ( 8 men, 7 women) aged 44-72 years (mean 59) were enrolled (see Table 1). Patients had different types of cancers, but the majority were sarcoma and head and neck cancer. More than half of the patients had been diagnosed for over two years. Two thirds of patients had a metastatic disease, and almost half were in recurrence.

\section{Insert Table 1 here}

\section{Procedure}

The interviews were conducted by a health psychologist using a semi-structured interview schedule. The schedule was based on Puchalski's definition of spirituality [11]. The set of questions included meanings, beliefs and representations of cancer, psychosocial management of illness and components of spirituality. During the interviews, we focused on some keypoints: the disclosure of the diagnosis, the causal attributions to cancer, how patients deal with difficult situations, the essential values and philosophy in the patient's life, relationships with friends, family and other individuals, and prospects for the future. For each question, we included the temporal sequences: "before disclosure of the cancer diagnosis" and "after disclosure of the cancer diagnosis". This instruction aimed to explore, through a reflexive task, 
whether we could observe any transformations in the processes of searching for and making sense of illness.

Every interview lasted 35-90 minutes. Interviews generally took place in patients' rooms. Interviews were fully-recorded on a voice recorder, once the patient's consent was given. The interviews were carried out within an ethical framework based on several key points: the guarantee of anonymity for the interviewees, the willing agreement of each interviewee and the possibility for each interviewee to view the data. Ethical approval for this research was obtained from the South Mediterranean CPP I (Committee 1 for the Protection of Persons, reference number: 2016-001090-51).

\section{Analysis}

The interviews were fully transcribed, and we conducted a double analysis of interviews: a lexicographical analysis and a thematic content analysis. As a first step, we conducted a lexicographical analysis using Iramuteq software [23] which allowed us to study the "lexical worlds" that structured the discourse. This method brings to light the most important lexical traces in the corpus collected [24]. The latter, reconstituted in the form of classes of discourse, can be grouped together in the form of themes [25]. The classes of discourse are related to the variables studied (sex, age, recurrence, metastatic status, duration of illness. The profile of a class is given by the set of words and variables most significantly associated with a discourse class, calculated by an association coefficient (Khi square or $\chi^{2}$ ). The more the Khi square is high, the more the force of association between variables is important. The Referential themes (sub-themes) can also be produced by the researcher on the basis of an analysis of the links between the themes associated with discourse classes [25].

In a second step, we conducted a targeted thematic analysis of the most representative interview of each class of discourse (identified by its $\chi^{2}$ association) produced by the lexicographical 
analysis. Indeed, the results from the Iramuteq analysis did not make complete sense of the data but consisted of a lexical "photography". The thematic content analysis allowed us to create themes to highlight the social and subjective construction of the illness experience and specifically, spiritual elements and their role in the patient's experience of illness. Following an immersion and familiarization phase, we tracked and selected the units of meaning related to our research problem to allow knowledge to be inferred [26]. The combination of the two analyses promoted both collective (highlighting the content and regulation of common discourses) and individual approaches (exploring individual discourse in accordance with a singular trajectory).

\section{Results}

The lexicographical analysis with Iramuteq highlighted three different classes of discourse (Table 1) which were testimony of the illness experience as "biographical disruption" [27], "personal transformation" and "description of daily life with illness". For each class of discourse, we will present, firstly, the characteristics of the class (most representative words, variable associated with the class, sub-themes) and, secondly, the thematic content analysis of the most representative interview.

\section{Cancer as personal transformation (Class $1-40.4 \%$ of the discourse)}

This class underlines the subjective experience of living with cancer. The most representative words were: to love (101), to change (88), something (331), rely on (56), to give (96), to try (97), important (100), thought (217), to live (133), really (85). Interviewees seemed to review and transform their priorities and values and define a new way of living. Moreover, giving and sharing constituted the discourse about the subjective experience of illness. This class is more typical of women $\left(\chi^{2}=13.09\right)$, patients in recurrence $\left(\chi^{2}=13.66\right)$ and patients with metastases 
$\left(\chi^{2}=9.79\right)$, suffering from sarcoma $\left(\chi^{2}=6.03\right)$ and gynaecological cancer $\left(\chi^{2}=36.16\right)$. The subthemes of Class 1 are presented in Box 1.

Insert Box 1 here

Representative interview of Class 1 - Mylène who has a metastatic cancer with recurrence, begins her discourse by referring to cancer as a biographic disruption. Her cancer appears, in the beginning, as a total upheaval of daily life, in which the personal, professional, familial and social order was destabilized. We observed a "before" and "after" cancer.

“I was a business leader... I managed 30 people and at some point, I gave up my job [...] my life completely changed, I stopped competing, I haven't stopped working because I now work in Human Resources, I don't do the same thing so I've adapted at work because I used to lead the company, but now... I'm employed you see? But financially it was difficult, I sold my house, I bought another house.” (Mylène)

We found this temporality during all interviews but not only in terms of disruption. Indeed, Mylène's experience of cancer appears as a time for re-evaluation of the values associated with life. Mylene expresses a new way "of being", of feeling and appreciating things, in the light of the cancer experience.

"It also gives you the means to appreciate what you have and live in the present, no obligation to earn lots of money and worry about the future, no it's about getting the best out of it for yourself and for others." (Mylène)

In her discourse, Mylène reflects on herself in order to get to know herself better and she presents the disease as a mean of accessing the real meaning of life. 
"It's changed, before I was quite aware, helped others and now I'm more aware than before but I feel that I have a need to help and to hear things and before I didn't know what it meant to receive." (Mylène)

"Many people don't know what is to live, it's not waking up, eating and sleeping (SILENCE) I think what my disease has given me is very, very profound." (Mylène)

Mylène's discourse seems involved with other elements related to spirituality. Indeed, the patient speaks about transcendence as a resource for living with cancer. Transcendence appears as a "faith" which allows you to transcend the aversive event, and surpass yourself through the experience of cancer, transmission (the dying individual can survive beyond the boundaries of their own existence by passing on values, skills and support) [28]. Mylène also drew on religious practices and beliefs to cope with the cancer experience: "I believe in God, I go to the chapel, I don't go to mass but every time I pass the chapel I like to go in, to light a candle and to pray". This interview highlights a spiritual path facilitating an adjustment to cancer and biopsycho-social repercussions. Indeed, Mylène's discourse presented cancer as being a liberating illness leading to self-accomplishment and personal enrichment.

There is a particular structure of temporality in this interview. Indeed, Mylene's discourse was, mostly, focused on the present with very few references to future, because it was uncertain. The present takes on a more intense value, Mylène emphasised the importance of living in the present moment.

"People talk about the past, before we did this, we compare, or we project into the future and we don't live in the present and we must live fully in the present, to appreciate, to know how to see past yourself, and for me the present is like a present,, it's a present of all the days that we must appreciate, to know how to say thank you." (Mylène) 
Another time perspective was discussed: the past as a background to spirituality. The spiritual path seems to have begun before the announcement of cancer and to be drawn on again during the experience of cancer.

“Yes, when was little I prayed, it was instinctive, I didn't know what prayer meant, I know that I prayed when I was little when my father beat my mother, whereas I didn't know what it was, I said "hail our father", I implored, it always helped me." (Mylène)

\section{The biographical disruption experience (Class $2-\mathbf{1 3 . 4 \%}$ of the discourse)}

The most associated words were: Announcement (26), shock (12), was (22), fight (17), beginning (10), after (10), test (8), life (101), physical (17). The topic of this class was the "biographical disruption" caused by the experience of cancer. Discourses were focused on the time of disruption, which leads us to consider illness as an extreme experience. Associated variables of this class were recurrence $\left(\chi^{2}=9.61\right)$, duration of illness beyond two years $\left(\chi^{2}=5.65\right)$ and aged 60 years and over $\left(\chi^{2}=11.02\right)$. The sub-themes of Class 1 are presented in Box 2.

Insert Box 2 here

Representative interview of Class 2 - Edward who was suffering from a recurrence of cancer expresses a particular temporality-structure. His discourse was organized around the disruption between the first time (initial cancer) and the second time (the recurrence). It seems that recurrence causes an additional disruption to the disruption, imposed by the first cancer.

"I'm going to be brief, the first time I wanted to die and the second I wanted to live." (Edward) 
For Edward, his first experience of cancer was marked by "lack of meaning". The initial cancer was experienced as an "extreme experience" which provoked many questions (causes, existential), driving the patient to search for meaning. The loss of meaning led to an internal struggle that Edward saw as being without solution. Edward was alienated by his cancer without a possibility of adjusting. Thus, for Edward, "lack of meaning" in the experience of cancer led to psychic upheaval.

"It's a wretched disease, it's a disease that I couldn't take in, so I wanted to die";

“Because I didn't understand why it had happened, I didn't understand." (Edward)

However, this recurrence appeared to be a time for re-evaluating the value associated with life and reflecting on oneself. Edward talked about a personal restructuring leading to a new way "of being", of feeling and appreciating life. This time of re-evaluation can be viewed as spirituality in the way that Edward develops his inner self.

"Another way of looking at it is, it's as if I was born again, because with this disease I learned to live, I became aware that life was important [silence] yes it's beautiful and now I know. Ok there is death, but it's not important to me" (Edward)

This contrast between the first time and the recurrence seems inherent in a relational issue expressed throughout the interview. We connected this contrast with spirituality as sacred (transcendence of our comprehension, intense emotional response, uniqueness, powerful for the individual, source of motivation and strength). Thus, Edward experienced the relationship to the sacred through the relationship with others. The relationships experienced by Edward are expressed as a new goal which allows him to improve his life but also to make sense of his cancer. This relationship transformed the illness experience.

“You don't know, because you are not me, how relationships are important to me, it's personal but really, with this relationship I see life differently, thanks to it I want to live." (Edward) 


\section{Daily life with the illness (Class $3-46.2 \%$ of the discourse)}

This is the most important class of discourse: interviewees' discourses about the description of daily life since diagnosis of the disease. Patients speak about their daily life by talking about communal activity since the announcement; they referred to a new pace of time imposed by illness. In addition, the discourse reflects that the illness is experienced in a family environment. The most significance words of this class are: going (459), chemotherapy (54), women (79), day (83), home (76), mother (53), putting (102), leaving (70), going back (50), week (55). This class of discourse is more typical of men $\left(\chi^{2}=13.63\right)$, patients under the age of $50\left(\chi^{2}=17.21\right)$, individuals not in recurrence $\left(\chi^{2}=33.11\right)$, without metastasis $\left(\chi^{2}=8.35\right)$, and patients suffering from urologic $\left(\chi^{2}=6.89\right)$ and head and neck cancer $\left(\chi^{2}=4.63\right)$, for two years or less $\left(\chi^{2}=5.92\right)$. The sub-themes of Class 1 are presented in Box 3.

Insert Box 3 here

Representative interview of Class 3 - André has a recurrence of cancer, in his discourse, he talks about a painful physical and psychic experience of the illness. Cancer is an extreme experience which causes disruption: "It ravages you, you see only disease, all you see is pain and suffering (...)”.

André describes a new temporality for which he wasn't prepared. He talks about both, the timeconsuming daily experience of cancer and treatments", and "his new daily rhythm of life imposed by cancer and treatments.

“My life, changed totally for the reason that I'm, I find I have wasted 2 years. I, I think that I lost lots of time in my life because I had to get treatment (...)"; "I have had 20 sessions of chemotherapy and 40 sessions of radiation. Morning, noon and evening we are in taxis, it's boring, all this." (André) 
This new daily routine is imposed not only on André because of cancer but also on his family (e.g., his wife had to leave her work to find a job closer to home). This upheaval caused by cancer seems to have led to a feeling of change in André's self both at a physical and physic level. In his discourse André explains that today he is not the man he was before cancer and who he wishes to be. He has become different, a stranger to himself: (...) I'm not me, my energy is not the same (...) As if to try and find the individual that he wants to be, André talked on several occasions about his life before cancer.

"I worked in social care for a local authority with senior citizens, so I took them to the doctor, to radiotherapy, to their mutual society, to their bank, I went with them, I took money to them, I was approved for this, and I was respected for myself and my way of life (...)" (André)

Moreover, in his discourse André valued the goals he had achieved, even with cancer.

"I was able to build a cottage and a garage, my wife helped me, she worked almost as hard as me (LAUGHS) and so it was my idea, my taste, my measurements, and bish bash bosh. I was able to build (...)" (André)

André also talked about two other changes in his life since the announcement of cancer. The first was a change of social relationship since cancer, the second change concerned values and life priorities.

"I reject outside relationships... Not reject, but... I'd rather be with the family... Now I don't speak to people who make you believe they are my friend and those friends, they are never here...It's all superficial... There are maybe 1 or 2 who come here." (André). “(...) We walk, just walk. We have found ourselves again here, it's been good for me. No need to have money to waste on stupid things... Just waves lapping against the rocks (...)" (André) 


\section{Discussion}

The main objectives of this study were, firstly, to explore whether we could find elements of spirituality in the patient's discourse and, secondly, to study how spiritual components were expressed in the distinctive/idiosyncratic experience of patients suffering from cancer in the French context. The two-step analysis allowed us to highlight components of spirituality in the cancer experience, as Puchalski [6] and other authors, for example Nixon and Naratanasamy [16] defined it.

Themes which emerged from the discourse of the patients interviewed showed different dimensions of spirituality. The first dimension refers to the re-definition of the meaning of life and life's goals. If existential questioning like the search for the meaning of life is a universal human experience, it has a central role in cancer [4,5]. It is not rare for a patient to change their life and life perception (e.g. life can be expressed as being more precious) by reworking their priorities and values [4,6], and expressing a new way of being, feeling and appreciating [5]. The second dimension refers to the connection with the "self" through accomplishment and self-reflection. In the literature, spirituality appears also as a connection to the self in the sense of a real relationship to the self, self-reflection and self-accomplishment $[6,8]$. Indeed, according to Fischer [30], an extreme experience such as cancer leads to both a loss of selfdimension and a new existential relationship with the self. This involves a painful perusal of the self before the disease [7]. The third dimension is the connection with others. Patients explain that cancer is a moment where they revalue relationships with others. This dimension is sometimes neglected in the literature [8]. In our interviews as in the literature, this dimension was expressed by patients in two ways. Firstly, they "excluded" some people from their affective environment and secondly, they expressed the desire to help and to love other people more. [17]. The fourth dimension refers to the connection with the present moment. Before the disease, patients were in "time-consuming" activities [7], they organized their life according to 
their future plans and past experience, heedless of their own death and present existence. But, diagnosis of cancer brings patients face to face with the awareness of present time. Indeed, their past experience did not prepare them for this event and their future is perceived as uncertain and threatening [5].

The representations of illness are a background against which the adjustment, experience and expression of spiritual components find meaning. Usually cancer is perceived as a "destructive disease" [29], while another representation of cancer appears in the discourse of patients as a "liberating disease". From this perspective, the cancer experience is considered as a time which allows life, the value of life and "ways of living to be redefined". According to this experience, patients could experience self-accomplishment and get rich at personal level. The representation of the "liberating disease" does not replace the "destructive disease" but there is a coexistence between these two conceptions for patients, and each representational dimension allowing people to cope with the cancer experience. Thus, spirituality seems to encourage the establishment of the "transition process", that Fischer [5] defines as a metamorphosis in which earlier beliefs and representations decrease or disappear in favor of others, bringing to the foreground a new way to live. Spirituality can be considered as an "invisible spring" allowing people to adjust to the cancer experience making an obstacle into a springboard, fragility into an asset (e.g., the precariousness of life as the preciousness and importance of life), and impossibility into a set of possibilities (e.g., the impossibility of continuing to work as an opportunity to take full advantage of the present moment) [30].

One of the most interesting results is the presence of two central dimensions of spirituality; transcendence and the sacred [12], in the discourse of the patients interviewed. Analyses allowed us to identify the presence of the transcendence dimension in different forms. Firstly, in the modalities of "faith". This type of transcendence is expressed (e.g., Mylène and André) as a way or an additional source of help in going beyond this difficult situation. Secondly, 
transcendence, in the sense of surpassing "oneself" through the cancer experience. For example, Mylène explains that since the cancer experience she has been able to go beyond her own personality, she has discovered the "best of herself". Thirdly, transcendence refers to transmission with the idea that the "dying human" can survive beyond the limits of their own existence by passing on values and expertise [28]. Expressions of transcendence by these patients reflect the way that it is defined in the literature: a belief in a superior being or higher power, which can be different from a "religious god" [15].

Furthermore, data analysis highlights the presence of the sacred [13], in particular through practices (praying, burning a candle) allowing a relationship with a higher power. Thus, this notion of the sacred appears in the discourses of religious and non-religious patients. Indeed, the sacred is expressed in different ways in the cancer experience of the patients interviewed. On the other hand, the sacred appears through elements of daily life, for example the couple relationship, children, mountains, the sea, values. These objects of daily life become sacred by a process of "sanctification". Through this process individuals perceive the secular aspect of life as having a significant and sacred aspect [14] which explains that the sacred can be considered in relation to non-religious patients.

An exploration of the spiritual components invites us to open new lines of thought on the integration of spirituality into patient care. Our results lead us to think that the consideration of spirituality, besides the biological, social and psychological dimensions, helps us improve our understanding and reflection on the cancer experience. Indeed, spirituality is often considered to be religiosity, thus the main fear about it in France is that it threatens the principle of secularity on which our hospitals and more largely our society are based. However, our results support the argument that spirituality is not just religiosity, it is more than religiosity, which is only an epiphenomenon of spirituality [7]. Indeed, through the analysis of discourses we 
highlight the "sacred" and "transcendent" at secular level, allowing us to think of the integration of spirituality into care as not posing a threat to the principle of secularity.

A recent meta-analysis highlighted that spiritual intervention as logotherapy based resilience in care of patient suffering from cancer have a moderate effect on spiritual well-being and depression [31]. Integration of spirituality in oncology can began by facilitate opening to spiritual with specific intervention as meaning making or meaning centered psychotherapy [31]. Psycho-oncologist can participate at this opening, by offers a place to existential questioning for the patient. We must be sensitive to this spiritual path of patients in order to support and encourage the development of existential questioning to give sense to life, and lived experience. This space will need to be sufficiently reassuring to allow the patient to advance along this sometimes strange and destabilizing path, as for them it includes a reevaluation of their existence, of their values, of their identity and existential foundations which give shape and meaning to their experience of the illness. The psychologist can support this "reference" to the self, making it possible perhaps to create a "psychic temple in which the patient can find peace and be elevated" [7] despite upsetting experience. By studying spirituality, our goal was to lead to a better understanding of the cancer experience in the French context, not to encourage a shift from "being" in a spiritual dynamic to "having to be" in this dynamic [15]. Indeed, in a context where health and well-being are norms addressed to collective [1,29] this shift could create a new injunction to patient. Our study provides evidence of the role of spirituality in the illness experience of cancer patients. As shown in previous studies, conducted in a large part in Anglo-Saxon countries, we found that spirituality allows individuals to adjust and give meaning to the illness experience.

\section{References}

1. Dany, L., Dudoit, E., \& Favre, R. (2008). Analyse des représentations sociales du cancer et de la souffrance [Analysis of social representations of cancer and pain]. Psychooncologie, 2: 53-58. 
2. Pierron, J.-P. (2007). Représentations du corps malade et symbolique du mal : maladie, malheur, mal?. Psycho-oncologie [Cancer and the symbolism of evil: disease, misfortune and evil?], 1: 31-40.

3. Santarpia, A. (2016). Introduction aux psychothérapies humanistes [Introductions to humanist therapies]. Dunod, Paris.

4. Da Rocha, G., Roos, P., \& Shaha, M. (2014). Le sentiment de finitude de vie et les stratégies de coping face à l'annonce d'un cancer [The feeling of finiteness of life and the strategies of coping during the announcement of a cancer]. Revue Internationale des Soins Palliatifs, 29: 49-53.

5. Fischer, G. N. (2008). L'expérience du malade : l'épreuve intime [Experience of illness : intimate event]. Paris : Dunod.

6. Puchalski, C. M. (2012). Spirituality in the cancer trajectory. Annals of Oncology, 23: 49-55.

7. Dudoit, E. (2015). Au cœur du Cancer le Spirituel [The spiritual at the heart of cancer]. Glyphe, Paris.

8. Edwards, A., Pang, N., Shiu, V., \& Chan, C. (2010). The understanding of spirituality and the potential role of spiritual care in end-of-life and palliative care: a meta-study of qualitative research. Palliative Medicine, 24: 753-770.

9. Zittoun, R. (2005). Comment répondre aux attentes des malades atteints de cancer en matière de croyances et de spiritualité ? [How to answer to expectations of patients suffering from cancer concerning believes and spirituality?]. Revue francophone de psycho-oncologie, 4: 296-298.

10. Wills, E. (2009). Spirituality and subjective well-being: Evidences for a new domain in the personal well-being index. Journal of Happiness Studies, 10: 49.

11. Puchalski, C., Ferrell, B., Virani, R., Otis-Green, S., Baird, P., Bull, J., ... \& Pugliese, K. (2009). Improving the quality of spiritual care as a dimension of palliative care: the report of the Consensus Conference. Journal of Palliative Medicine, 12: 885-904.

12. Koenig, H. G. (2008). Concerns about measuring "spirituality" in research. The Journal of Nervous and Mental disease, 196: 349-355.

13. Pargament K. (2007). Spiritually Integrated Psychotherapy: Understanding and Addressing the Sacred. Guildford, New-York.

14. Pargament, K. I., \& Mahoney, A. (2005)." Sacred Matters: Sanctification as a Vital Topic for the Psychology of Religion". The International Journal for the Psychology of Religion, 15: 179-198.

15. Pujol, N. (1994). Spiritualité et cancérologie : Enjeux éthiques et épistémologiques d'une intégration [Spirituality and cancerology: Ethical and epistemological stakes for an integration]. Doctorat de l'Université Paris Descartes, Paris.

16. Nixon, A., \& Narayanasamy, A. (2010). The spiritual needs of neuro-oncology patients from patients' perspective. Journal of clinical nursing, 19: 2259-2370.

17. Baker, D. C. (2003). Studies of the inner life: The impact of spirituality on quality of life. Quality of Life Research, 12: 51-57.

18. Smith, T.-B., McCullough, M.-E., Poll, J., 2003. Religiousness and depression: evidence for a main effect and the moderating influence of stressful life events. Psychological Bulletin, 129: 614-636. 
19. Jafari, E., Najafi, M., Sohrabi, F., Dehshiri, G. R., Soleymani, E., \& Heshmati, R. (2010). Life satisfaction, spirituality well-being and hope in cancer patients. ProcediaSocial and Behavioral Sciences, 5: 1362-1366.

20. Brady, M. J., Peterman, A. H., Fitchett, G., Mo, M., \& Cella, D. (1999). A case for including spirituality in quality of life measurement in oncology. Psycho oncology, 8: 417-428.

21. Kennedy, J. E., \& Kanthamani, H. (1995). Association between anomalous experiences and artistic creativity and spirituality. Journal American society for Psychical Research, 89: 333-343.

22. Breitbart, W. (2002). Spirituality and meaning in supportive care: spirituality-and meaning-centered group psychotherapy interventions in advanced cancer. Supportive Care in Cancer, 10: 272-280.

23. Ratinaud, P., \& Marchand, P. (2012). Application de la méthode ALCESTE à de "gros" corpus et stabilité des "mondes lexicaux" : analyse du "CableGate" avec IRaMuTeQ [Application of ALCESTE method at « big » corpus and stability to « lexical word»: analyse of "CableGate"]. Actes des 11eme Journées internationales d'Analyse statistique des Données Textuelles, 835-844.

24. Reinert, M. (1990). Alceste une méthodologie d'analyse des données textuelles et une application : Aurelia de Gérard De Nerval [Alceste a textual methodology of data analysis and an application: Aurelia de Gérard De Nerval]. Bulletin de Méthodologie Sociologique, 26: 24-54.

25. Kalampalikis, N., \& Moscovici, S. (2005). Une approche pragmatique de l'analyse Alceste [A pragmatic approach of the Alceste analysis]. Les Cahiers Internationaux de Psychologie Sociale, 15-24.

26. Dany, L. (2016). Analyse qualitative du contenu des représentations sociales [Qualitative analysis of the content of social representations]. In : G. Lo Monaco, S. Delouvée \& P. Rateau (Eds.), Les représentations sociales (pp. 85-102). De Boeck, Bruxelles.

27. Bury, M. (1982). Chronic illness as biographical disruption. Sociology of Health \& Illness, 4: 167-182.

28. Raoul, M., \& Rougeron, C., (2007). « Besoins spirituels des patients en fin de vie à domicile, à propos d'une étude qualitative auprès de 13 patients " [Spiritual needs of end of life home care patients: a qualitative study with 13 patients]. Journal International de Bioéthique, 18: 63-83.

29. Herzlich, C. (1969). Santé et maladie : analyse d'une représentation sociale [Health and Illness: analysis of social representation]. Mouton, Paris.

30. Fischer, G.-N. (1994). Ce ressort invisible en nous : l'expérience du malade [Invisible spring: experience of patient]. Dunod, Paris.

31. Oh, P. J., \& Kim, S. H. (2014). The effects of spiritual interventions in patients with cancer: a meta-analysis. Oncology Nursing Society, 5: 290-300. 
Table 1. Characteristics of the patient's sample $(n=15)$

\begin{tabular}{lc}
\hline Characteristics & $\mathrm{n}(\%)$ \\
\hline Age & $2(13.3)$ \\
$<50$ & $6(40.0)$ \\
$50-60$ & $7(46.7)$ \\
$>60$ & \\
Gender & $8(53.3)$ \\
Men & $7(46.7)$ \\
Women & \\
& \\
Cancer type & $6(40.0)$ \\
Sarcoma & $5(33.4)$ \\
Head and Neck & $3(20.0)$ \\
Urologic & $1(6.6)$ \\
Gynecological & \\
Disease duration & \\
$\leq 2$ years & $6(40.0)$ \\
$>2$ years & $9(60.0)$ \\
Metastatic cancer & \\
Yes & \\
No & $10(66.7)$ \\
Recurrence & $5(33.3)$ \\
Yes & \\
No & \\
\hline
\end{tabular}


Box 1. Sub-themes and interview extracts for Class 1 - Cancer as personal transformation

\section{(a) Restructuring priorities and values}

"It also gives you the means to appreciate what you have and live in the present, no obligation to earn lots of money and worry about the future, no it's about getting the best out of it for yourself and for others

"[...] You just have to be, in the sense of thinking about yourself and your loved ones, of others and the world., not just navel-gazing, that's it. It's true that with my children I try to make them aware...I'm more concerned about them being happy, rather than asking them what they've earned or if they they're going to work."

\section{(b) Redefinition of ways of life}

"Many people don't know what is to live, it's not waking up, eating and sleeping (SILENCE) I think what my disease has given me is very, very profound

"I think it's a restful way to live, there's no urgency us to make decisions, ... It doesn't occupy your mind in an intrusive and oppressive way, when we have a plan we know that we will do it even if it's not immediately and we aren't stressed wanting to carry it out immediately. This, teaches me to be calmer, more serene and tells me that the important things can be counted on the fingers of one hand $[\ldots] "$

\section{(c) Donation and sharing}

"So, when I give, when I give, I give my time, my love, my happiness in life, I give my positivity, all this, it's the best I can do, it's, it's, it's, it's the fact that I receive in return [...]"

"Immortality it's, it's as I said before, it's about sharing with others, we, we...They remember us and then we become immortal." 
Box 2. Sub-themes and interview extracts for Class 2 - The biographical disruption experience

\section{(a) Moment of disruption}

"It destroyed me because it was painful, I say that's the end of my chemo."

"[...] the day of the announcement was a big shock. We said that it was, it was the end of real life."

"How do you explain this hum very bad news, because I didn't expect to hear news like that... it was a complete upheaval, I even asked myself whether it was a disease which could be cured (...)"

\section{(b) Cancer as extreme experience}

"It's a wretched disease, it's a disease that I couldn't take in, so I wanted to die [...]"

"So, my life, on the day when I learned that I was ill, the ground collapsed under my feet. I radically changed my life because I couldn't work, I'm a woman who had worked a lot before. I worked all my life, I'm hyperactive but I can't work [...]"

"[...] It was an upheaval for me, for my family and what changed was that life became fragile, I said I want to live, it's fragile, it's all hanging by a thread [...]" 
Box 3. Sub-themes and interview extracts for Class 3 - Daily life with the illness

\section{(a) Account of daily activity since the announcement}

"[...] I sleep all day. I know that for 15 days, almost 3 weeks I slept, they fill you with stuff and send you home, and, to stop you getting infections the hospital fills you with antibiotics [...]"

"I realize that this disease doesn't allow me to be carefree, I always have to be thinking about something, when I go to sleep remember to put cream on, when I wake up remember to take my medication, when I get dressed don't rub too hard [...]"

\section{(b) New rhythm of life imposed by disease}

"I have had 20 sessions of chemotherapy and 40 sessions of radiation. Morning, noon and evening we are in taxis it's boring all this."

"[ ...] the disease has not taken over completely, but there are treatments, appointments, things like that."

\section{(c) Life with cancer involving the family}

"She (his wife) had to leave her job for to me and take a new job closer (...)"

"[...] My husband has organized things so he can always be with me, that means a lot to me [...]"

"[...] There's my mum who is 81 years old, she is always brave. I go to her home during treatment, I prefer her [...] she can keep an eye on me, she saw that's it's not so bad, but the trouble my family has gone to has touched me, I'm aware that they do lots, lots of important things for me [...]" 